\title{
DINAMIS POINTER
}

\section{DWI MIFTAHUL JANAH \\ 185110022}

Fakultas Komputer

dwimiftahuljanah.student@umitra.ac.id

\begin{abstract}
Pointer merupakan salah satu jenis data terstruktur. Dengan menggunakan pointer, suatu variabel dapat diciptakan atau dihapus selama pengeksekusian program, variabel dinamis adalah suatu variabel yang akan dialokasikan pada saat diperlukan saja, yaitu saat program dieksekusi. Dengan menggunakan variabel dinamis ini, dimungknkan untuk membuat struktur data dinamis seperti link list,queue,stack dan tree.

Pada struktur data dinamis, terdapat variabel yang disebut variabel pointer (secara singkat disebut pointer), yaitu variabel yang menunjuk alamat memory pada variabel dinamis.secara umum dapat dikatakan bahwa variabel pointer merupakan suatu variabel yang menyimpan alamat dari suatu objek. Karena itu sebenarnya variabel pointer bukan berisi data, melainkan berisi alamat dari suatu data. Secara singkat pointer artinya menunjuk ke sutu lokasi data. Pointer harus dideklarasikan dan diberi nama serta dikaitkan dengan suatu tipe. Tipe ini disebut tipe dasar atau tipe domain dari pointer tersebut, dimana tipe ini menentukan tipe dari variabel dinamis yang akan ditunjuk oleh pointer yang bersangkutan. Untuk ilustrasi, pointer akan digambarkan sebagai anak panah dan lokasi memory sebagai segi empat.

Dalam variabel dinamis, nilai data yang ditunjuk oleh suatu pointer biasa disebut dengan simpul/node. Simpul biasanya berupa suatu record (dapat juga tipe data yang lain kecuali yang menyangkut file).
\end{abstract}

Kata Kunci : Dinamis

Pointer 


\section{A. PENDAHULUAN}

Salah satu kelemahan data bertipe array adalah bahwa variabel tersebut harus dideklarasikan terlebih dahulu dengan menyebutkan ukurannya. Dengan demikian ukuran variabel tersebut tidak dapat kita ubah selama program dijalankan. Lalu bagaimanakah kalau kita akan membuat program untuk menangani data dalam jumlah yang besar? Bagaimana pula kalau jumlah datanya tidak diketahui sebelumnya?.

Pertanyaan pertama mungkin dapat diselesaikan dengan memesan variabel array dengan ukuran sebanyak data yang akan dimasukkan. Tetapi sebenarnya ide ini belum tentu dapat dijalankan (terutama kalau implementasi programnya menggunakan bahasa yang mensyaratkan ukuran maksimum variabel dalam suatu program, seperti Pascal yang membatasi jumlah ukuran semua variabel dalam suatu program tidak boleh melebihi 64 $\mathrm{Kb}$ ). Sebagai contoh, berikut ini adalah deklarasi dalam Pascal yang akan ditolak:

1. var banyak : array[1..35000] of integer;

2. var larikan : array[1..12000] of real;

3. var larik1 : array[1..30000] of char;

4. var larik2 : array[1..35000] of byte

Pendeklarasian di atas akan ditolak oleh Pascal karena:

1. ukuran variabel banyak adalah $35000 \times 2$ byte $=70000$ byte

2. ukuran variabel larikan adalah $12000 \times 6$ byte $=72000$ byte

3. ukuran variabel larik1 $=30000 \times 1$ byte $=30000$ byte dan ukuran variabel larik $2=35000 \mathrm{x}$ 1 byte $=35000$ byte, sehingga total ukuran kedua variabel adalah 65000 byte

Permasalahan kedua juga menyulitkan pemrograman. Bila kita alokasikan variabel dengan ukuran yang besar sementara nantinya data yang dipakai hanya sedikit maka ini berarti pemborosan memori (memori sudah dipesan tetapi tidak dipergunakan) sedang bila dialokasikan dengan ukuran kecil sementara nantinya data yang digunakan cukup banyak sehingga deklarasi yang dibuat tidak cukup maka tentunya permasalahan tidak akan terselesaikan.

Untuk mengatasi permasalahan di atas maka pada beberapa bahasa pemrograman terstruktur diperkenalkan adanya dua jenis variabel yaitu variabel statis (seperti yang sudah dibicarakan pada bagian sebelumnya) dan variabel dinamis yang akan kita bicarakan pada bagian ini. 


\section{B. PEMBAHASAN / STUDI KASUS}

\section{Alokasi Memori Dinamis}

Alokasi memori dinamis dapat dikatakan merupakan suatu teknik alokasi memori dimana, tidak seperti pada penggunaan array,penggunaan memori tidak sekaligus pada saat variabel dideklarasikan (dipesan) tetapi dengan bertahap. Program berjalan pada awalnya dengan sedikit memori data, kemudian pada suatu saat bila memerlukan ruang/memori lagi (misal datanya bertambah) barulah program meminta memori yang diperlukan untuk keperluan tersebut kepada sistem.

Dengan cara yang sama bila program sudah tidak memerlukan data lagi maka memori yang diperlukan untuk menyimpan data dapat dibebaskan. Memori yang dibebaskan ini selanjutnya mungkin untuk proses yang lain (pada multiprogramming) atau untuk keperluan program yang sama nantinya.

\section{Pointer}

Pointer sering disebut juga dengan istilah link atau referensi adalah suatu variabel yang berisi alamat dari suatu variabel yang lain.

Sebagai contohnya pada saat kita mengakses record kita tidak tahu dimana record tersebut secara eksak diletakkan di dalam memori, karena dengan menggunakan pointer kita membiarkan sistem komputer mengatur letak record tersebut ketika diperlukan.

Secara umum, dalam pembicaraan tentang pointer, tipe data pointer digambarkan sebagai tanda panah sedang variabel yang ditunjuk digambarkan sebagai kotak.

\section{Variabel Statis dan Variabel Dinamis}

Variabel statis adalah variabel yang dideklarasikan dan dinamai pada saat penulisan program. Memori yang dipakai oleh variabel ini akan tetap ada (dianggap terpakai) selama program dimana variabel tersebut dideklarasikan sedang dijalankan.

Variabel dinamis adalah variabel yang dibuat (dan mungkin juga dihapus/dirusak) selama eksekusi progam. Karena variabel dinamis belum nyata ada pada saat program dikompilasi ${ }_{f}$ ia 
nyata-nyata ada pada saat dibuat yaitu pada saat program dieksekusi), maka variabel seperti ini tidak dapat dinamai pada saat program dibuat/ditulis.

Satu-satunya cara untuk mengakses variabel dinamis adalah dengan menggunakan pointer. Saat suatu variabel dinamis dibuat, ia belum berisi data dan harus memiliki suatu tipe tertentu seperti halnya variabel biasa.

Sebaliknya variabel statis tidak dapat dibuat ataupun dihapus pada saat eksekusi program dan variabel pointer tidak dapat digunakan untuk menunjuk kepada variabel statis. Variabel statis dapat diakses hanya dengan menggunakan namanya dan bila kita ingin menunjuk pada suatu posisi dalam array maka kita dapat melakukannya dengan menggunakan indeks/variabel yang bertipe seperti indeks dari array.

\section{$\underline{\text { Notasi dalam Pascal }}$}

Pointer dalam Pascal dinyatakan dengan menggunakan tanda “^”. Sintaks secara umum adalah :

type nama_pointer $=$ $\wedge$ tipe_variabel_yang_ditunjuk atau

var nama_pointer $=$ $\wedge$ tipe_variabel_yang_ditunjuk

Keterangan:
- $\quad n a m a \_p o i n t e r$ adalah pengenal untuk tipe data pointer

- tipe_variabel_yang_d itunjukadalah tipe data variabel dinamis yang ditunjuk oleh pointer Tipe variabel ini bisa berupa tipe sederhana (integer, char, boolean, word) atau tipe yang lebih kompleks (real, record,array)

Contoh:

1. type item = integer; pointitem $=\wedge$ item; pointnode $={ }^{\wedge}$ integer; var ptr_ke_int : pointitem; 2. $\quad$ var a,b :pointitem; c,d : pointnode;

Keterangan :

1. Pada contoh a)

- tipe item adalah sama dengan tipe integer - tipe pointitem adalah tipe pointer yang menunjuk data bertipe item - tipe pointnode adalah tipe pointer yang menunjuk data bertipe integer 2. Pada contoh b) - variabel $a$ dan $b$ bertipe pointitem - variabel $c$ dan $d$ bertipe pointnode

Kalau diperhatikan, pada contoh b) di atas keempat variabel $(a, b, c \text { dan } d)_{6}$ 
semuanya merupakan variabel

pointer yang menunjuk ke variabel

bertipe integer. Meskipun

demikian karena tipe dasarnya

berbeda (variabel $a$ dan $b$ bertipe

pointitem sedang variabel $c$ dan $d$

bertipe pointnode) maka dianggap

bahwa variabel $a$ dan $b$ memiliki

tipe yang sama, demikian pula $c$

dan $d$, tetapi $a$ tidak dapat

disamakan dengan $c$ atau $d$.

Dengan demikian assignment $\mathbf{a}:=$

$\mathbf{b}$ dan $\mathbf{c}:=\mathbf{d}$ adalah sah, tetapi $\mathbf{a}:=$

d adalah ilegal.

Membuat Dan

Menghapus/Merusak Variabel

$\underline{\text { Dinamis }}$

Dalam bahasa Pascal, pembuatan variabel dinamis dapat dilakukan dengan prosedur standar $\mathbf{N E \boldsymbol { W }}$.

Bila $p$ adalah variabel pointer ke tipe node maka prosedur :

NEW(p) akan menghasilkan suatu variabel dinamis bertipe node dan memberikan alamatnya ke pointer p.

Untuk menghapus, merusak atau mengembalikan memori yang dipakai oleh variabel dinamis dapat digunakan prosedur dasar

DISPOSE, misalnya DISPOSE(p)

berarti mengembalikan memori

yang ditempati oleh variabel

dinamis yang ditunjuk oleh pointer

$p$ ke sistem.

\section{Pointer Bernilai NIL}

Kadang suatu variabel pointer $p$ tidak menunjuk ke suatu variabel dinamis. Ini dapat dilakukan dengan memberikan assignment p:= nil. Perlu dibedakan pengertian variabel pointer yang bernilai NIL dengan variabel pointer yang tak terdefinisi (tak tentu). Variabel pointer bernilai NIL berarti ia tidak menunjuk ke suatu variabel dinamis, sedang variabel pointer yang bernilai tak tentu berarti ia mungkin mengacu (menunjuk) ke suatu lokasi sembarang di memori. Dengan perintah DISPOSE(p) maka akan berakibat $p$ menjadi tak tentu sehingga disarankan untuk mengassign dengan nilai NIL setiap kali suatu variabel dinamis dibebaskan (misal p :=NIL)

\section{CATATAN}

Untuk mempermudah pemahaman tentang variabel pointer, berikut ini adalah cara pengartian tanda "^", bila diberikan deklarasi p : ^item:

- $\quad \mathrm{p}:{ }^{\wedge}$ item berarti $p$ menunjuk ke suatu tipe item - $\quad \mathrm{p}^{\wedge}$ berarti apa yang ditunjuk oleh p 
Dengan demikian bila $p$ dan $q$ adalah dua variabel pointer bertipe sama, maka assignment $\mathbf{p}:=\mathbf{q}$ dan $\mathbf{p}^{\wedge}:=\mathbf{q}^{\wedge}$ adalah legal. Meskipun demikian mereka mempunyai pengertian yang berbeda. $\mathbf{p}:=\mathbf{q}$ berarti $p$ dan $q$ menunjuk ke lokasi yang sama, sedang $\mathbf{p}^{\wedge}:=\mathbf{q}^{\wedge}$ berarti $p$ dan $q$ menunjuk lokasi yang berbeda tetapi isi variabel dinamis yang ditunjuk keduanya sama. Jadi assignment yang kedua dapat diartikan seperti halnya meng-copy-kan isi variabel $q$ ke variabel $p$ sehingga isi keduanya sama.

\author{
C. ID SECURITY \\ QWTD4452377-ASP- \\ 5244107
}

\section{DISKUSI}

Apakah kekurangan artikel ini ?

Yuanita : mungkin tambahkan sedikit lagi contoh tentang dinamis pointer

Apakah kelebihan artikel ini?

Yuanita : dapat di mengerti dengan mudah dan cara penyampaiannya singkat jelas dan padat 


\section{E. KESIMPULAN}

Jadi apa yang sudah di jelaskan diatas adalah kesimpulannya.

Alokasi Memori Dinamis dapat dikatakan merupakan suatu teknik alokasi memori dimana, tidak seperti pada penggunaan array,penggunaan memori tidak sekaligus pada saat variabel dideklarasikan (dipesan) tetapi dengan bertahap.sedangkan Pointer sering disebut juga dengan istilah link atau referensi adalah suatu variabel yang berisi alamat dari suatu variabel yang

lain. Sebagai contohnya pada saat kita mengakses record kita tidak tahu dimana record tersebut secara eksak diletakkan di dalam memori, karena dengan menggunakan pointer kita membiarkan sistem komputer mengatur letak record tersebut ketika diperlukan.

Variabel statis adalah variabel yang dideklarasikan dan dinamai pada saat penulisan program.

Memori yang dipakai oleh variabel ini akan tetap ada (dianggap terpakai) selama program dimana variabel tersebut dideklarasikan sedang dijalankan.

Variabel dinamis adalah variabel yang dibuat (dan mungkin juga dihapus/dirusak) selama eksekusi progam. Karena variabel dinamis belum nyata ada pada saat program dikompilasi (ia nyata-nyata ada pada saat dibuat yaitu pada saat program dieksekusi), maka variabel seperti ini tidak dapat dinamai pada saat program dibuat/ditulis.

\section{F. REFERENCE}

[1] O. M. Febriani and A. S. Putra, "Sistem Informasi Monitoring Inventori Barang Pada Balai Riset Standardisasi Industri Bandar Lampung," J. Inform., vol. 13, no. 1, pp. 90-98, 2014.

A. S. Putra, "Paperplain:

Execution

Fundamental Create Application With Borland Delphi 7.0 University Of Mitra Indonesia," 2018.

A. S. Putra, "2018 Artikel Struktur Data, Audit Dan Jaringan Komputer," 2018.

[4] A. S. Putra, "ALIAS

MANAGER USED

IN DATABASE

DESKTOP

STUDI CASE DB DEMOS."

[5] A. $\mathrm{S}$.

Putra,

"COMPREHENSIV

E SET OF PROFESSIONAL FOR DISTRIBUTE COMPUTING."

[6] A. S. Putra, "DATA

ORIENTED 


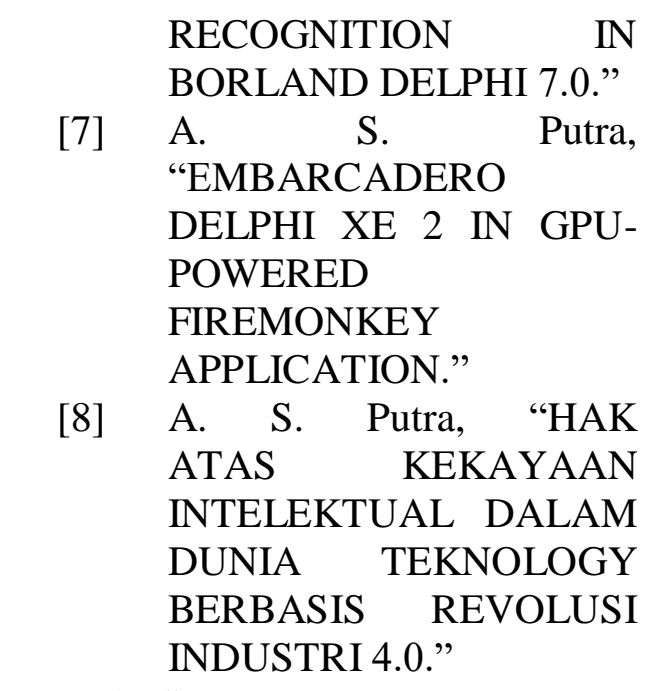

[9]A. S. Putra,

"IMPLEMENTASI

PERATURAN PERUNDANGAN

UU. NO 31

TAHUN $2000 \quad$ TENTANG

DESAIN INDUSTRI BERBASIS

INFORMATION

TECHNOLOGY."

[10] A

$\mathrm{S}$.

Putra, "IMPLEMENTATION OF

PARADOX DBASE."

[11] A. Putra, "IMPLEMENTATION OF TRADE SECRET CASE STUDY SAMSUNG MOBILE PHONE."

[12] A. S. Putra, 
"IMPLEMENTATION

PATENT FOR APPLICATION

WEB BASED CASE STUDI

WWW. PUBLIKLAMPUNG. COM."

[13] A

"IMPLEMENTATION

SYSTEM FIRST TO INVENT IN DIGITALLY INDUSTRY."

[14] A. S. Putra, "MANUAL REPORT \& INTEGRATED DEVELOPMENT

ENVIRONMENT BORLAND DELPHI 7.0."

[15] A. S. Putra, "PATENT AS RELEVAN SUPPORT RESEARCH."

[16] A. S. Putra, "PATENT FOR RESEARCH STUDY CASE OF APPLE. Inc."

[17] A. S. Putra, "PATENT PROTECTION FOR APPLICATION INVENT."

[18] A. S. Putra, "QUICK REPORT IN PROPERTY PROGRAMMING."

[19] A. S. Putra, "REVIEW CIRCUIT LAYOUT COMPONENT

REQUIREMENT ON ASUS NOTEBOOK."

[20] A. S. Putra, "REVIEW TRADEMARK PATENT FOR INDUSTRIAL TECHNOLOGY BASED 4.0."

[21] A. S. Putra, "TOOLBAR COMPONENT PALLETTE IN OBJECT ORIENTED PROGRAMMING."

[22] A. S. Putra, "WORKING DIRECTORY SET FOR PARADOX 7."

[23] A. S. Putra, "ZQUERY CONNECTION IMPLEMENTED
PROGRAMMING STUDI CASE PT. BANK BCA Tbk."

[24] A. S. Putra, D. R. Aryanti, and I. Hartati, "Metode SAW (Simple Additive Weighting) sebagai Sistem Pendukung Keputusan Guru Berprestasi (Studi Kasus: SMK Global Surya)," in Prosiding Seminar Nasional Darmajaya, 2018, vol. 1, no. 1, pp. 85-97.

[25] A. S. Putra and O. M. Febriani, "Knowledge Management Online Application in PDAM Lampung Province," in Prosiding International conference on Information Technology and Business (ICITB), 2018, pp. 181-187.

[26] A. S. Putra, O. M. Febriani, and B. Bachry, "Implementasi Genetic Fuzzy System Untuk Mengidentifikasi Hasil Curian Kendaraan Bermotor Di Polda Lampung," SIMADA (Jurnal Sist. Inf. dan Manaj. Basis Data), vol. 1, no. 1, pp. 21-30, 2018.

[27] A. S. Putra, H. Sukri, and K. Zuhri, "Sistem Monitoring Realtime Jaringan Irigasi Desa (JIDES) Dengan Konsep Jaringan Sensor Nirkabel," IJEIS (Indonesian J. Electron. Instrum. Syst., vol. 8, no. 2, pp. 221-232.

[28] D. P. Sari, O. M. Febriani, and A. S. Putra, "Perancangan Sistem Informasi SDM Berprestasi pada SD Global Surya," in Prosiding Seminar Nasional Darmajaya, 2018, vol. 1, no. 1, pp. 289-294. 